\title{
The Role of Islamic Fundamentalism in Algeria
}

\author{
DR ZOLA SONKOSI \\ Department of Political Science, University of Durban-Westville
}

\section{Algeria and the Islamist challenge}

For six years, Algeria has been experiencing a true nightmare of terror. Human rights organisations estimate that since 1992, 120000 people were killed' by armed Islamic groups or state security ${ }^{2}$, among them many civilians. During Ramadan 1998, there were shocking news of cruelly executed and mutilated women, men and children in Koraa, 80 kilometres south-west of the capital Algiers ${ }^{3}$. The alleged culprits were assumed to belong to the Groupe Islamique Armée (GIA). The critical Algerian press increasingly becomes a victim of fanaticism and state censorship ${ }^{4}$. In order to understand these events better, it is necessary to take a look at the history of this country. In 1962, Algeria celebrated its independence from 132 years of colonial occupation by France. This great event was preceded by a long and bitter war, which was led by the Front De Libération Nationale (FLN), and its ally, the Armée de Libération Nationale (ALN). In 1954 , Algerians began to fight the French army that was considered unbeatable. Its defeat was achieved in 1962, but the country was never exposed to democracy and pluralism because the FLN-leadership preferred to practice one-party-rule after the Soviet model. Critics, especially from the ranks of former freedom fighters, among them Mohamed Boudiaf and Hocine Ait Ahmed, were arrested or forced to go into exile.

The man who stood at the beginning of the 'new' Algeria was Ben Bella. 1965 marked the end of his reign and the then minister of defence, Colonel Houari Boumedienne, organised a putsch and became the undisputed chairman of the party, head of state, government and army as well as minister of defence until his death in 1978. The new state president appointed a revolution council, consisting mainly of members of the military and acting as a substitute for parliament and the FLN Politburo. Military omnipotence was consolidated and personified in Boumeidenne, the president. Since 1968, Belaid Abdessalem, Boumedienne's minister of industry and energy, carried out the transfer of American and French oil companies to the state owned oil company

\section{1}

Gsteiger, Fredy 1997. Lieber schieben als reden, in Die Zeit 31 January 1997, p. 14 and Schirmbeck, p. 425 .

2

Amnesty International reported a legal moratorium on executions and mentioned the torturing of alleged and known Islamists. It was mainly the notorious Sécurité Militaire (SM) which Chadli Bendjedid renamed into the Département Recherche et Scurité (DRS), to signify democratic renewal. The 'Ninjas', a special police unit are notorious for state terror.
Cape Times, Cape Town, 22 December 1998.

Until the end of 1995, 120 foreigners and 120 intellectuals were killed. Schirmbeck, p. 400.

In 1962, Mohamed Boudiaf founded the party for Socialist Revolution, was arrested by the state president Ben Bella and sentenced to death. He was able to escape into Moroccan exile; from there he returned to Algiers in 1992 as the president of the High State Council and was murdered in the same year by one of his bodyguards. Hocine Ait Ahmed was an opponent to the central government since independence. In 1963, he founded the Front des forces socialistes (FFS), was arrested by the Bella-regime in 1963 and sentenced to death. In 1965 he was pardoned and forced to go into exile. In 1989, Ait Ahmed retumed home and left it again in 1962 due to political developments. 
SONATARCH. With its industrial and agricultural nationalisation policy, Algeria dared to 'send the West home and stand on its own feet economically'. 6 Natural gas and petroleum are income sources that created great wealth ${ }^{7}$ for the country in the 1970's. Thanks to the petro-dollar, Algeria became a model country for the so-called Third World nations. ${ }^{8}$ Algeria established an extended social net for its own population', which was to symbolise justice to the outside world. The euphoria around social and economic upliftment left unnoticed the fact that party and army cadres personally benefited from the country's wealth: Algeria created its own Socialist party and army millionaires.

The goals were too ambitious; from the beginning, Algeria could not realise its plans. Plans for agricultural reform failed - in 1990, the country imported up to 70 percent of its foodstuffs - even basic foods. Because of faltering productivity, which decreased by 50 percent, the black market began to flourish, controlled by high-ranking state officials and economic stakeholders. The Marxist Boumedienne regarded the elimination of social discrepancies as an important task. However, at the end of his life, the social tensions among Algerians were as strong as never before. For the majority of the population, Islamic Socialism as a social concept meant endless queues and supply problems. "The blessing of the black gold threatened to turn into a curse."10 The socioeconomic catastrophe that had been anticipated for a long time became acute with the crash in the oil price in 1986. Boumedienne's presidential successor, Chadli Benjedid, made a tentative attempt to disentangle the net of corruption but failed due to the power of his opponents. However, Benjedid made an attempt to rescue the situation by opening Algerian markets internally and externally. Western companies were permitted to reestablish themselves in the country, pluralistic elections were announced, but it was already too late.

During the last thirty years, Algeria experienced a population explosion. In 1962 the country had ten million citizens. Today, with a growth rate of three percent, it has to feed about 27 million people.

The conditions that would allow the country to master this task are not there. ${ }^{11}$ The education system the French left behind was in shambles. In 1962, only 15 percent of the

Herzog, Werner 1995. Algerien: zwischen Demokratie und Gottesherrschaft. München: Beck, p. 57.

7 In 1980 the income from its oil trade was 98 percent of the Algerian state income. Ibid., p. 60.

In 1974, Algiers hosted the Fourth Summit of Independent States. In the same year, Boumedienne delivered a remarkable speech to the General Assembly of the UN, in which he denounced the NorthSouth difference and demanded a more justice in the world.

For example, Algeria included the so-called National Charta, the provision of free health care as a principle in Article 76 of its constitution. The rapid increase in population and problems in strategic planning made this ambitious project impossible to implement. The construction of hospitals could not keep up with these developments, the country had to pay high costs for the import of 80 percent of its medicines. At the beginning of the 1980 s, the project was gradually phased out and private medical care was re-introduced.

Herzog, p. 60.

11 About two million flats are needed in Algeria at the moment, the big cities in the North attracted people from the rural areas for decades. Problems arise from the typical Socialist way of constructing flats with the help of concrete slabs (Plattenbau). The flats are usually too small for a family of eight or more people - the literature refers to 'sleeping in layers' as a result. The traditional Algerian quarters have deteriorated; its inhabitants have been long forgotten by the state. From these quarters (such as the Kasbah or Bab El Oued in Algiers) the liberation army recruited its underground fighters. Today, it is controlled by the Islamists. On the other side, there are an estimated 65000 expensive state owned apartments and villas which are rented out to foreigners for foreign exchange. 
Algerian children went to school, in 1995, 90 percent attended school. Quantity rather than quality dominate education: only 15 to 30 percent of all matriculants pass the Baccalaureat. ${ }^{12}$ President Ben Bella already began the Arabianisation of schools. Fearing the leftist intellectuals, Boumedienne pushed the policy of Arabianisation and gave the responsibility for teaching Arabic dialect, whereas public life is dominated by French. As a result, Algerian teachers complain that school leavers are 'bilingual but illiterate'. ${ }^{13}$ The job market requires French-speaking matriculants or university graduates. With increasing unemployment $(25$ percent $){ }^{14}$ the language issue became an existential identity problem. France as the former colonial power and the West in general personified the enemy for the unemployed who had received their education in Arabic and who had little chance of employment in the French speaking production and administrative sectors.

Algeria has been overtaken by its own mismanagement. Hogra - the Algerian term for abuse by the strong and the powerful - is felt everywhere. Hogra also means humiliation and this is felt by many Algerians who suffer under a Mafia dominated party and army apparatus. The high rate of unemployment and the production capacity being reduced by 50 percent are partly a result of the "good business" which powerful state officials conduct in a climate of economic failure. The majority of the Algerians is disillusioned. Already in the 1960 's, the small group of leftist francophone intellectuals opposed the betrayal of the idea of freedom and was increasingly forced into line by the political leadership. The Algerian youth represents the third group of frustrated and disappointed Algerians. ${ }^{15}$ They were told about the injustices that are committed by the Algerian political leadership in the name of modernism and Socialist state capitalism are experienced by them on a daily basis. These youngsters, the hittestes (wall supporters) and the trabandistes (smugglers) who are simply called les laisses pour compte (the one that were left behind, the defenceless) began to defend themselves: in 1986 during the student unrests and 1988 during the five bloody days of wrath. "Many frustrated youths joined the fundamentalists."16

An eye for an eye, a tooth for a tooth - this has been the strategy that plugged the country into a cruel war between two factions since 1992. "There is no war of one half of the population against the other, rather between two factions at the cost of the majority of the population." 17 The majority of the population includes thousands of civilians who were victims of the terror, either because they were accused of being Islamists, of supporting them or of being related to them, or because they were victimised by the Islamists as non-believers. The historical overview presented a few important answers to questions like the 'What' and the 'Why' behind the current events. The culmination of events during the period from 1988 to the beginning of 1992 is discussed in this article.

\section{The anger of the youth}

Since 1986, 'wild' work stoppages had been accumulating all over the country - in October 1988, rumours of an impending general strike began to emerge. During the night of the fourth and the early morning of the fifth of October, young people from the poor

Herzog, p. 136.

Ibid., p. 137.

Bühmer, Gerd 1997. Algerien brennt. Der tagliche Terror. Special programme of the ARD (channel 1) on the situation in Algeria, 30 January, 22.00 - 22.30.

75 percent of the population is younger than 30 years of age.

Herzog, p. 138.

According to the Algerian writer Habib Tengour, quoted from Schirmbeck, p. 424. 
quarters of Bab El Oued in Algiers marched to the centre of the capital and began to unleash their anger about the generally worsening situation in the form of pure aggression against all state property. "At first, stones were thrown. To take up stones, aim at state symbols and destroy them provided a possibility for these young people to cleanse themselves of the humiliations endured by the system. A discussion about the role of religion, the state, and the citizens has been suppressed for decades. Now they had been pre-empted with one blow." 18 During the following days and nights, thousands of young people joined the October-revolt. ${ }^{19}$ Such deep anger was unexpected in Algeria and by its powerful leaders.

The rumours of a general strike had been spread by the conservative FLN-faction in order to put an end to the liberalisation attempts of the president and his prime minister Mouloud Hamrouche because they were threatening the existing power relations. At the beginning of the revolt, the struggle for power between the orthodox and the reformers reached a climax that explains the fact that the security forces began to act relatively late. Finally, the state put an end to the 'Frustration-Revolt' using firearms. About 500 young people were killed, thousands were arrested and tortured. For the first time in the history of the Republic of Algeria, a state of emergency was declared and the population was shocked and traumatised because the national army had pointed weapons at its children. The government believed the leftist faction to be behind this wrath, namely the PAGS. ${ }^{20}$ The powerful turned a blind eye to the frustration of the population or the role of the Islamists during the revolt.

\section{The 'appearance' of the Islamists}

Algeria's history shows that the government, especially under Boumedienne supported the Islamists. Islam had always been state religion - the 1976 'National Charta' named Islam and Socialism the pillars of the Algerian State. In 1963, the Algerian Oulemas coined a (quasi) constitutional formula: "One religion: Islam, one language: Arabic, one nation: Algeria". ${ }^{21}$

In this way, two different parties with two different goals supported the policy of Arabianisation: on the one hand, the secular fight against the francophone and francophile cultural influence. Boumedienne's principle in this regard was: "Science must be in the hands of the francophone elite, culture in those who support Arabianisation. ${ }^{22}$

The state took responsibility for the education of the Imams and the building of mosques. Boumedienne appointed the Islamic High Council which later became the Ministry for Religious Affairs. The inclusion of the Islamists in state affairs even led to the direct influence the minister of religion had on the education system. The state was well informed about the explosive nature of this arrangement but the religious leaders were too important for official politics and it was therefore attempted to control them by affiliating them with the state. Yet the contradictions remained embedded in different

Ibid., p. 63.

19 In Europe, the five days of wrath of the Algerian youth became known as the 'Couscous-Revolt', With this term, the European journalists referred to the shortages of ingredients for the main national dish. It remained unnoticed that there was much more at stake. It was only in December 1991 that Algeria made headlines again in the Western news.

PAGS is the Parti de I'avantgarde Socialiste, the successor to the Algerian Communist Party.

21 Herzog, p. 145.

22 Schirmbeck, p. 75. 
models of society: the regime wanted a "reformed and a 'reasonable' Islam". 23 Religion was to be an instrument of power. The Islamists, however, did not want to be used and have pursued the idea of an Islamic state ever since the victory of the Iranian revolution. While the regime talked about Islamic Socialism, the Islamists meant Islam.

Under Bendjedid, the orthodox family law ${ }^{24}$ was passed. On the other hand, the president did not allow the Islamists to engage in political activity. This manifested itself in the 1982 arrest of three leading Islamists: Sheikh Ahmed Sahnoun, Sheikh Abdulatif Soltani and Professor Abassi Madani. During a demonstration of the Islamic fundamentalists on the campus of the Bab Ezzouar University of Algiers, they had delivered a Communique, called the Declaration of Advice. This document became known as the foundation document of the Islamic movement. It accused the state of corruption, economic mismanagement and oppression. ${ }^{25}$

Since the 1970's, the formation of a religious opposition ${ }^{26}$ in the 'wild' mosques ${ }^{27}$ had begun. The Shari' $a$ state according to the Iranian model was openly discussed. The religious leaders saw themselves as a practical alternative to the mismanagement of the state. They organised for instance cheap groceries for 'Islamic' markets, ${ }^{28}$ offered support in dealings with the bureaucracy, gave extra lessons to pupils, etc. These religiously inspired people appeared to be modern Robin Hoods. In this practical way, the Islamists gained the trust of the people, especially the young people who were impressed by their rhetorical courage, because they openly acknowledged what everybody thought. Deep religiousness played a subordinate role. But religious belief and a sense of social belonging led from passive to increasingly active resistance. In the 1980's, the number of wild mosques that were tolerated by the state grew. The government did not realise that it tolerated its enemies.

It was mentioned above that the revolt of the youth was a spontaneous release of anger, i.e. political goals or even demands were non-existent. In the course of this bloody revolt, Sheikh Abassi Madani and Sheikh Ali Belhadj negotiated with the government and presented the Islamists as 'protectors' of the people. Afterwards, the Islamic fundamentalists politically exploited the October events to their own advantage. The religious leaders became more confident and began to make concrete demands regarding

Herzog, p. 146.

In 1984, this controversial law was passed which permits polygamy, declares women incapable of mature judgement, determines that women are legally disadvantaged in the case of divorce and does not permit Muslim women to marry non-Muslim men. This law contradicts the 1976 constitution which provides for equality of the sexes.

In November 1982, an illegal Islamic court had convicted the leftist Kabyl Kamal Amzar. He was sentenced to death and executed. Thereafter, violent riots ensued between Islamists and the police at the Central University of Algiers. The policy had found an illegal arms depot in the university mosque and intended to put an end to violence. As a result, there was a protest meeting of Islamists at the university campus that ended in mass arrests, among which were the above-mentioned Sheikhs. This opposition was decisively influenced by Egyptian teachers of Arabic who were, as mentioned above, mostly supporters of the Muslim brothers.

Due to the fact that the state could only exert control over a mosque once it was completed, unfinished building became wild mosques. It must however be distinguished between so-called 'people's mosques' which withdrew from state control and advocated a religious life free of ideology and the 'wild' mosques which were used to condone anti state propaganda on religious ground.

These people's markets are found in the poorer quarters which also housed the religious leaders. 
Islamic every day life: Female students who wore miniskirts, jeans or make-up were reprimanded or even beaten by fanatic Islamic fellow students. ${ }^{29}$

\section{The process of democratisation as a rescue attempt}

In 1988, President Bendjedid emerged from the internal power struggle with the conservative leadership in the military and within the party as a winner and started the process of democratisation in the wake of the October-revolt and the international development. ${ }^{30}$ Bendjedid attempted to reform the centre of political power by dissolving the politburo and by pushing for a separation between the FLN and the government/ office of the president. He also achieved a constitutional reform in February 1989 against the interests of the apparatchiks. From a legal point of view, the introduction of democracy and a pluralistic party and press system could go ahead.

However, the political difficulty was that there existed no alternative to the to the FLN in Algeria - the unity party had exclusively dominated the country and critical voices from the bourgeouis-leftist spectrum had been suppressed for many years. Against this background, it was difficult for those parties that established themselves legally since 1989 to identify guidelines or debate basic political issues such as Algeria's cultural identity $^{31}$ or social future. Many parties imitated the old game of the FLN - using the party as a means to gain advantages for its own clan members. Still, Algerians now had the opportunity to choose from 60 parties. Among the most well-known democratic groupings are the PAGS, the FFS (Front des Forces Socialistes), led by the Berber and national liberation hero Hocine Ait Ahmed, the RCD (Rassemblement pour la Culture et la Democratie) which is a splitting off from the FLN headed by Said Sadi, and the MDA (Mouvement pour la Democratie en Algerie) of the first president Ben Bella. The governing party wanted to be regarded as a reformed liberal-democratic party. The religious spectrum was represented by the moderate MSI-Hamas (Mouvement pour une Societe Islamique), led by Sheikh Mafoud Nahnah, and the En Nahda, as well as FIS. The 1989 constitution permitted all parties that were not exclusively motivated by religious or regional issues. The FIS, which openly formulated its religious opinions and demands was presumably accepted because Prime Minister Hamrouche needed the FIS to eliminate the conservative FLN-wing or because the process of democratisation did not allow for any other decision. However, the great success of the religious leaders was not expected.

"The politicians talked about laws and elections - but the population talked about problems of every day life which became more and more pressing." ${ }^{32}$ The first free elections in the history of Algeria took place on June 12, 1990. In the provincial and local elections, the majority of Algerians voted against the worsening supply situation. As a consequence of the gradual opening of the Algerian market and the attempt to privatise desolate state owned companies, unemployment increased, prices rose due to the removal

Appearances became increasingly important. Women were supposed to wear the Hidjab. The men became used to wearing the Qamis (an ankle-long shirt), Babouches (slippers) and a beard.

A policy of opening up to the international community was only possible for Algeria because of the fact that the two major power blocks moved closer together and the Soviet Union began its Glasnost/ Perestroika politics in 1986.

Algeria is not a homogeneous country but displays a cultural and historical diversity. The Berbers are the largest minority group that has not been recognised by the state and which continues to make the question of cultural identity a topic. The Berbers, the Arabs and the French occident influence Algeria. This cultural complexity must be taken into account because its complicated social layers are at the root of the country's present problems. 
of price control by the state, and the Algerian Dinar increasingly lost value. The electorate was disappointed by this development: 54 percent of the voters supported the FIS and only 28 percent voted for the reformed FLN and the democrats. ${ }^{33}$ This result prompted speculations regarding parliamentary elections which were planned for the summer of 1991: Who is the FIS, what does this religious party want and what is the origin of its success?

\section{The Islamic Salvation Front}

On September 6, 1989, the FIS, the Islamic Salvation Front was officially recognised. It was founded in February 1989 in the Al Sunna mosque of Bab El Oued. ${ }^{34}$ Its name and place of foundation are indicators of the party programme which strictly adheres to the Quamran in all social questions. Since its foundation, it has been led by the above-mentioned Abassi Madani and Ali Belhadj. ${ }^{35}$

In March 1989, the FIS presented its political programme which proclaims the social Islamisation on the basis of the Shari'a. The FIS also demanded the restructuring of the centrally planned economy through privatisation. According to the Islamists, the Islamic state must create the necessary socio-political framework and ensure that it complies with the concept of an 'Islamic market economy'. ${ }^{36}$ It is interesting that financial aid for this ambitious programme is expected from Muslims living in foreign countries and from other Islamic countries. This type of investment can be summarised under the term 'financial Djihad'. The role of science and technology is emphasised as research is the only way to provide for coming generations in a responsible manner and aid present developments. The countries' own productivity must receive special attention in order to increase it. To this end, industry and agriculture must enter into a productive partnership in order to free Algeria of imports and international credit. The formation of monopolies must be avoided as only a sensible functional division between companies could re-activate the 'economic blood circulation' which is the trading of products made in Algeria. The decade-long corruption and profiteering had to come to an end as the Prophet said: "Whoever is cheating is not one of us." ${ }^{38}$ With regard to external trade, the Algerian Islamists are considering an Arab-Islamic union which could compete with the European market. All the efforts must be directed at increasing exports rather than imports. A plan with different phases could be used to implement free trade, beginning with the internal Algerian Trade. The FIS is planning to introduce an Islamic social tax (zakat) and Islamic charities (awgaf) in order to fulfil its obligations with regard to the needy members of the community. Funds for social solidarity were to be established as a

$33 \quad$ Ibid., p. 177.

34 One of the traditional, now completely impoverished quarters in Algiers.

35 Born in 1931 near Batna, Abassi Madani was a member of the FLN before 1954, studied philosophy and science of education, received his $\mathrm{PhD}$ in London and was then professor of sociology and science of education in Algiers. He benefited from the non-interference of the FLN-regime in affairs of religious leaders and was able to spread his Islamic teachings unhindered. After the October events, he became a father figure for the Islamists.

36 Meier, 1994, p. 411.

37 The term 'Islamic market economy' can be understood as a constructive joining together or marketrelated, socialist and Islamic elements. Together with the socio-political responsibility of all Muslims regarding the community, the FLN demanded self-sufficiency and the overcoming of economic underdevelopment. The state's tasks are organisation and control. In this sense, the FIS could be regarded as a modern Islamic party displaying a cross between Islamic and market-related elements. 
preventive measure to assist in times of economic and social emergency. The 'financial Djihad' plays a functional role in the development of a finance policy which attempts to implement the political, social and economic project within the Islamic state. Within this concept, Islamic banks, credit and savings accounts would carry the responsibility for all financial transactions in the interest of the public. ${ }^{39}$

The highest FIS decision-making committee is the Madjliss Echoura (the executive committee). Just like the FLN/ ALN regime, the internal functioning of the Salvation front remains a mystery. The number and political orientation of the Madjliss Echoura members is changing constantly and the meetings are secret. But in 1990 and 1991, the FIS supporters showed little or no interest in these proceedings as they were used to the same tactics being employed by the FLN.

"The FIS supporters were far from being a homogeneous group as was believed by the FIS leadership and its blindness to this fact was to lead them to errors with far reaching consequences." 40 FIS supporters can in fact be classified in the following way: On the one hand, there are young people, often unemployed, who are earning their upkeep as black marketeers. Samuel Schirmbeck calls these young people the 'Jogging-FIS', because they usually wear Western style youth fashion such as sneakers and track suits. They often lack sound Islam knowledge and are easily captured by rhetorical and passionate speeches of young Salafist Imams. For them, religion means autonomy from the state and it is for this reason that they enjoyed participating in Islamic demonstrations and going to the mosques. "However, they have little respect for the Islamic moral norms." ${ }^{41}$ On the other hand, there are the so-called 'identity FIS' or 'intellectual FIS' supporters. Their goals are much more moderate and their representatives are office clerks, public servants, business people, craftsmen, scientists, teachers, engineers, medical doctors, lawyers, students, etc. - generally all those who are disappointed by the system and had or have no chance of social improvement or professional fulfilment. It is the business people in particular who expect a lot from the Islamic market economy after the FLN had imposed its economic policy on them for years. It is also them who have been financing the party's social work for years. The intellectuals, mostly scientists and engineers, are hoping for employment in an Islamic state because of their Arabic education which may be required. ${ }^{42}$ In a 1990 television interview, Abassi Madani said: "The FIS is able to reach all levels of the Algerian society". ${ }^{43}$ Before 1992, the Islamic worker's union Syndicate Islamique du Travail (SIT) increased its membership within the companies because it was a forum for real worker's grievances as opposed to the FLN trade union UGTA led by Abdelhak Benhamouda ${ }^{44}$ for many years. In 1990 the FIS had

Despite all negative experiences with such institutions in Iran and Pakistan, the FIS is advocating Islamic finance institutes. The economic concept reveals the diversity of party supporters - all the diverse groupings are taken into account. However, the concept does not include any concrete recommendations, i.e. it sounds good but its implementation would be limited even with an Islamistic government. At least, the FIS declared its economic and political intentions as opposed to many other parties.

Schirmbeck, p. 152.

See also statements by Mohamed Harbi, the Algerian historian and former political advisor to Ben Bella in Schirmbeck, pp. $207-208$.

See amongst others Schirmbeck, pp. $192-207$.

Madani, quoted from Schirmbeck, p. 201.

According to many Algerian unionists, Abdelhak Benhamouda was a favourite of the 'FLN-Serail'. He ruled the state union in a despotic manner. The interests of the employees seemed to be of little importance. The consequences were 'organised' low productivity, a high unemployment rate and wild strikes. Abdelhak Behamouda was shot dead on January 28, 1997. 
won the parliamentary and local elections and most provinces and communities were governed by the Salvation Front. They could not change much because the government wanted to stop the Islamists and removed the community's right to make budget decisions. The FIS were planning structural changes which had become impossible because of state intervention. In addition, the Islamists' ban on alcohol and the closure of discotheques ${ }^{45}$ were unpopular in some places. Because of their moralistic exaggerations, the Islamists were often simply called La yadjous (This is not permitted). The 1990 voters had expected something different.

\section{Algeria decides on its future}

A parliamentary election was announced for 27 June 1991. Forty-two parties prepared themselves for this day. Without any doubt, the FIS was the party with the best chances - Abassi Madani wanted to announce an Islamic Algeria that same year. He wanted total power for his party, therefore he demanded a presidential election for 1991. The FIS threatened a general strike if their demands were not met. The government and army reacted to such claims to power by the Muslims. Werner Herzog quotes an unnamed Algerian politician who summarised the happenings that took place between the summer of 1991 and March 1992: "They placed the Holy Front on an escalator, accelerated the process and caused it to fall., 46

The government manipulated the right to vote, i.e. a majority vote system. ${ }^{47}$ The FLN speculated during the run-up that there would be a neck-to-neck race with the candidates of the FIS. However, in order to counter all doubts about victory, they brought their influence to bear on the local election regulations. The south was given more constituencies than they should have had with regard to population, whereas the densely populated north was seen as an FIS stronghold and was consciously disadvantaged in this way in favour of the government party. According to the new basic law, every person entitled to vote, both male and female, had to vote personally. Until then, the presentation of the entitlement to vote by a family member, usually a male head of the family, was sufficient and he would vote for all the others. The sexes were given separate voting rooms so that this would be acceptable to both the new democratic rules and to tradition.

Within the FIS there was disagreement between the wings because the Salafists rejected the constitution and the elections as unreconcilable with Islam, so for a long time there was no certainty that the party would take part in the elections. The annoyance over the disadvantaging division of constituencies went so far that the FIS called for a general strike - although this had no far-reaching response. ${ }^{48}$ After the Hamrouche government had negotiated with the Muslims, the police and army took action. There were violent street massacres after which a state of emergency was declared that lasted for four months. The two leaders of the FIS, Madani and Belhadj, were arrested and in the summer of 1992 they were each sentenced to twelve years in custody. The liberation army then openly took over the governing of Algerian politics, because the government of the 'uncomfortable' Mouloud Hamrouche had to resign as a result of its liberalising

\footnotetext{
45

Because leisure activities were offered to the Algerian youth - football, music and the mosques.

An unnamed Algerian politician, quote from Herzog, p. 90.

The first-pass-the-post electoral system prefers that, with an absolute majority at the first election, the candidate in question goes to parliament. If none of the candidates get an absolute majority, then the first two candidates in the first election enter a deciding ballot - whoever gets a simple majority goes to parliament.
}

People from the Salvation Front occupied squares and public buildings in Algiers. 
policy. The parliamentary elections were subsequently postponed for an indefinite time. The Djazairist Abdelkader Hachani was made the new speaker of the FIS and he pleaded in July 1991 for a legal path to be followed. Hachani managed to achieve the domination of the Djazairists in the newly elected 'Nadjliss Echoura' and the FIS participation in the parliamentary elections was confirmed. ${ }^{49}$ The parliamentary elections which took place on 26 December 1991 were not a sensation for Algeria, but an event for the Arab world, because the question was posed, as to what will become of the Arab despots if the Algerians blossom from being a mere subject to being a citoyen (citizen) ${ }^{50}$ On 24 December 1991 the president of the Algerian republic declared his readiness to co-operate with the election victors of whatever political colour, which could be understood as a clear offer to the FIS. The election day proceeded calmly - the result was only available on 28 December. A shock went through the democratic ranks in the country and there was jubilation from the side of the Islamic supporters for the FIS was victorious with 47,59 percent (according to the votes). The former governing party only received 23,28 percent. The poll turnout was 59 percent. $^{51}$

\section{The unfinished democracy}

In the spa suburb Club des Pines, 25 kilometres west of Algiers, seven generals, the real rulers of Algeria, met a few days after the FIS victory: the minister of defence, Khaled Nezzar, the general chief of staff, Abdelmalek Guenaizia, Mohamed Lamari, commander of the land forces, Mohamed Touati, chief of the operational division in the general staff, Bennabes Ghezaiel, commander of the national gendarmerie, and Mohamed Mediene, chief of the Military Security. ${ }^{52}$ In the Club des Pines the top members of the military decided on Algeria's future. It was decided not to go to the polls for the second time, for there was a distinct possibility that the FIS would have an absolute victory. A military intervention after the elections would be too dangerous because there were religious people, or at least religious sympathisers, within the ranks of the military. In no way could the external unity of the army $y^{53}$ - its strength - be endangered. The military attempted to make contact with the democratic parties - Hocine Ait Ahmed rejected the offer as functioning as a dummy for military intervention, and called for a March for Democracy on 2 January 1992, in order to mobilise the 41 percent of non-voters for the second round of elections. The democratic motto for this event, which was finally abused by the army for its own ends, was 'Neither Islamic Republic nor Police State'. On 11 January President Chadli Bendjedid had to announce his premature resignation, ${ }^{54}$ because this was the only way for a legal postponement of a second election. The then former president was furthermore forced to dissolve parliament to prevent the parliamentary president Abdelaziz Belkadem, who was closely associated with the Muslims, from taking over presidential duties for the time being. Legal advisers to the Government decided that the interim presidency could be carried out by the council of Internal Security Control, the High Security Council. The military decided on precisely this strategy. The 'High Security Council' was convened and represented by five members of the military. The Cf. Schirmbeck, p. 234. Ahmed Rouadjia, author of the book Les Freres et la Mosquee, ascribes a generally middle attitude between 'mythical Orient' and 'actual Occident' to the Djazairists.

Cf. With this amongst others Ibid,. p. 248 and 249.

Ibid., p. 252.

Because here the clan and directional struggles, which are deciding the Algerian policy, take place internally.

Bendjedid's term of office only finished at the end of 1993.
} 
military attempted to legitimise the coup ${ }^{55}$ as an action for the salvation of democracy in that they named a man as president of the High Security Council who had been arrested and sentenced to death by the military in 1963 because of his democratic attitude and democratic activities. Mohamed Boudiaf could only save himself at the time by fleeing and staying in exile for almost thirty years.

On 11 January 1992, President Chadli Bendjedid, the initiator of the democratisation process, departed unwillingly from the political stage and on 16 January, the date of the planned second election, Mohamed Boudiaf returned to Algiers as the president of the High Security Council.

\section{The military policy}

Week after week the Friday prayers heated up the situation between the rulers and the Muslims who were claiming the right to rule. The government erected internment camps for FIS activists. Approximately 15000 people were arrested. On 9 February a state of emergency was declared. It was clear to everyone that it was only a question of time before the FIS was banned. On 3 March 1992 an Administrative Court in Algiers pronounced judgement to this end. The leading FIS representatives had already fled abroad, like Rebah Kedir, the confidant of Abassi Madani, or, as has already been said, were interned in their thousands, amongst them Abdelkader Hachani. The banning of the FIS meant the negating of the will of three million FIS voters - with this decision the military released a war on two fronts. Many of the young FIS supporters and sympathisers went underground, and afterwards the Salafists gained from the internal FIS squabbles. Muhamed Boudif saw the cul-de-sac of the road they had taken, and he appealed to the youth that he wanted to give them a future in secular Algeria. However this he could not do, because he was murdered on 29 June 1992 by one of his bodyguards. The orchestrators of this attack were generally believed to be in the ranks of the military.

\section{Terror and counter-terror}

"You cling more to death than to life." This general characterisation of the new religious terrorist type was also the opinion of the Algerian Jihad fighters whose Emirs and group leaders often belonged to the so-called 'Afghans', called 'Araf' for short.

55 There are contradicting points of view to be read in the literature. One speaks of a coup-d'etat, the other that they are not dealing with the same thing as the president has resigned and been replaced by the security service - in principal everything was as before. The latter position was represented for example by Bassam Tibi 1992, pp. 207 - 209, who sees democratic catastrophe in the political taking over of power by the Islamists.

L'Orient-le-jour, of 30 April 1996, quote from Sigrid Faath and Hanspeter Mattes (eds.), Die 'Arabschen Afghanen'. Faktor interner Konflikte in Nordafrikal Nahost und des internationalen Terrorismus, in: wuquf-Kurzanalysen, no. 4 of 20 August 1996, p. 32.

'Afghans' are Islamic fanatics who fought in the Afghanistan war against the atheistic and communist Soviet Union on the side of an international Moudjahidin army. The fighters were trained in Pakistan in camps which were conducted by, paid for and logistically equipped by, amongst others, the West and even by the CIA. They are a professional guerrilla group whose aim is a martyr's death in which they want to take as many unbelievers as possible with them. The internationality of the Afghan fighters creates a worldwide network for religious terrorists in the 1990's, which is also present in Europe. Their struggle has not ended by any means, because now their aim is the setting-up of a caliphate. For this reason the Jihad of the 1990's is directed at the atheistic, socialist or Western oriented governments in the Islamic world. Nowadays already the second generation of the Araf is fighting on the 'home fronts'. These young men received their military training in Pakistan without being directly involved in the Afghanistan war. 
Algeria had approximately 500 Arafs who had returned to their homeland after the fall of the Najibullah regime in Afghanistan in 1992. They are the ones who put in place the forces of law and order of the FIS and who belong to the Salafist wing. Their preference right from the start was for armed struggle in accordance with the example of Mustapha Bouialis. ${ }^{58}$ The Salafists used the FIS congress in Batna in the summer of 1991, from which the two former Afghanistan fighters were excluded due to pressure from the Djazairists, to go underground to the Maquis, and so to force a break with the party.

In 1993, the founding communique of the GIA, the Groupe Islamique Arme, became known as a counter movement to the armed wing of the Djazairists, the Arme Islamique du Salut (AIS). In the GIA several armed groups under the command of a national Emir were brought together. They reject any negotiations with the state, for them the only thing that counts is the absolute abolition of their enemies, the unbelievers. They even kill civilians in their fanaticism. Women, even girls who are not wearing Hidjab; children who attend a mixed school; and passers-by who happen to find themselves at the place of attacks may be victims. They abduct and rape young girls and women. ${ }^{59}$ The West has learned mainly of the numerous murders of democratic thinking intellectuals journalists, writers, doctors, lawyers, teachers, actors, singers, etc. This could be referred to as 'intellectocide'. Anyone who speaks up for democracy is a potential murder victim. The FLN system always considered the democrats to be enemies - today they are the targets of both state and Islamic attacks.

Since 1 December 1993 foreigners have also become victims of GIA attacks after an ultimatum that demanded their immediate departure from the country had expired. In December 1993, 12 Croatian electro-workers in Tamesguida had their throats slit, whereas nothing happened to their Muslim Bosnian colleagues. The Jihad reached a religious turning-point with this massacre and was extended to Europe in $1995 .^{60}$

The danger and brutality of the GIA resides in their uncompromising attitude and ideological blindness. The sympathisers blame their opponents for so-called 'unjust' murders, like those of innocent civilians. Propaganda and counter-propaganda is the order of the day. Many Algerians only learn of the attacks through the foreign media, for the state's official version is always that the terrorists have almost been 'wiped out' - in such a situation anything seems probable. The Maquis had no problem finding new fighters for the Jihad. The life expectancy there is on average only six months. However the Maquis has a wide appeal to the youth which can only be rooted in the deep hatred of the system and their lack of trust in those in power or in other political structures.

\footnotetext{
58 Mustapha Bouali showed himself to be responsible in the 1980 's for a series of terrorist attacks on state security forces in Algeria. He was friendly with Ali Belhadj and was shot in 1987 by an antiterrorist unit. The survivors of his armed group belong to the leading GIA Emirs. If these women have a son they are sometimes married - but for most of them death is waiting or a rejection by their own family because of disinheritance. This crime, especially, discredits the selfappointed fighters for God with the population.

France, the one time colonial master, experienced a series of bomb attacks probably caused by the GIA, after the hijacking of a French airbus at Christmas 1994. The last attack took place on 4 December 1996 in a suburban train in Paris. The Islamic fundamentalists gave as the reason for the attacks on foreigners and on Europe that they want to force world opinion over to the side of a change in Algerian politics. On this topic see the interview with Khaled Kelkal who was involved with the series of attacks and shot by security forces in Lyon on 29 September 1995, Moi, Khaled Kelkal, in Le Monde of 7 October 1995, pp $10-11$, see appendix.
} 


\section{Destroyers versus reconcilers}

After the murder of Muhamed Boudiaf, Ali Kafi became his successor as president of the High Security Council, and Belaid Abdessalem took over the office of prime minister from Sid Ahmed Ghozali. Both represented a hard line, the so-called destroyer strategy with regard to the Maquis. However the top politicians stood for the 'old' Algeria - the much beseeched break with the system is not spoken of any more. Algeria has experienced a period of political stagnation which is only interrupted almost daily by terrorist attacks. Abdessalem resorted to orthodox methods. One of his first acts was to limit press freedom. Seven newspapers were immediately banned and the others adversely affected by censorship and reduced paper deliveries. The new-old people in power reacted to the GIA and AIS nightmare with intense repression, namely random arrests of well-known and supposed Islamic fundamentalist. Torture is the order of the day in prisons. Citizens who are suspected of supporting the armed groups also become victims of state reprisals. $^{61}$

\section{Political normality in an abnormal situation}

Can terrorism only be counteracted with anti-terrorist measures? Is it at all possible to negotiate with the Islamic fundamentalists? In answer to the second question it must be stressed that "the FIS must react to the ever-present terrorism if it does not wish to go out of politics." ${ }^{, 2}$ In 1996 the FIS took up the political fight. In contrast the GIA carried out a religious war which excluded negotiations, as they only accepted a theocracy based on the Shari'a. The Djazairsits, who today represent the FIS, want national and international recognition. They put this at risk, however, with their long silence over the acts of violence by the Maquis. However, their political trump card is their contact with and influence on the AIS as well as the GIA. Abassi Madani is still regarded as the father figure of the Islamists. Since their participation in the negotiations in Rome, the FIS has regained credibility. In the 'Platform of Rome ${ }^{, 63}$ the FIS, together with the FLN, the FFS, the MDA, the PT (workers party), the Algerian Human Rights League (LADDH) and the two moderate religious parties En Nahda and JMC (Modern Algerian Muslim party), supports the cessation of violence, the upholding of human rights, and demands the withdrawal of the army from politics as well as the democratic change of power on the basis of free and pluralistic elections. The democrats who took part in the Rome negotiations are pleading for negotiations with the Islamic fundamentalists, for only thus can terrorism really come to an end.

Many Algerians only see an effective alternative to the Islamic terrorist fundamentalist commandos in the powerful ALN because the latter still enjoys standing and respect from the days of the war of liberation. The military power reacted angrily to the declaration from Rome, because they would like to solve the matter alone and according to their judgements in order to retain and legitimise their claim to absolute power. At the end of 1993, as announced by the government, the High State Council was

61 It is a completely merciless war on two fronts with the civilians in the middle and with both sides keeping close tabs on them. Many Algerians have to pay Jihad taxes which provide the terrorists with shelter and supplies, and place women and girls at their disposal. This is forbidden by the state. The civilian population is imprisoned in its own country. The GIA gets weapons from, amongst others, Europe and by ambushing security forces. The military training of the former 'Afghans' is also to their advantage, and they are financed by donations from Iran and Saudi Arabia. Schirmbeck, p. 380 .

63 This is also called the 'national contract' and was worked out over several months by the given parties. The negotiations took place under the patronage of the Monastery of Sant'Egidio. 
dissolved and removed at the beginning of 1994 by the president of Colonel Liamine Zeroual who had been appointed by the military. Zeroual was regarded as a magician. The new head of state sharpened the state's fight against the Maquis but at the same time set out on a reconciliatory course with them. He had Madani and Belhadj released from prison and placed under house arrest so that he could negotiate the end of terrorism with them. ${ }^{64}$ But Zeroual went even further. He announced, in the middle of the societal 'chaos', the presidential elections for the end of 1965 . $^{65}$ The GIA wanted to drown this legalistic act in blood. However Liamine Zeroual represented the opinion that only a president elected by the people could present a really trustworthy alternative to terrorism. He estimated that the psychological effect of his concept of a political normality would be great.

There was great general confusion with regard to the Zeroual suggestion. The question was: who would support the president? From the democratic side came the accusation that parliamentary elections without the participation of all political groups, including the FIS, could not be held, as they would misrepresent the Algerian reality. Apart from that it was more necessary to hold parliamentary elections in order to entrust a government legitimised by the people with the tasks facing them. In order to hold the elections, a generally recognised armistice had to be negotiated. All these points made the three parties, who were amongst the winners in the 1991 elections - the still banned FIS, the reformed FLN and the democratic FFS - to call for a boycott.

On 16 November 1995, the presidential elections took place. The supporters were afraid of the poll because the success of the Zeroual strategy depended on a quota that was as high as possible. But soon it became clear that the Algerian population wanted an end of terrorism, because 25 percent of the people entitled to vote went to the polls - despite GIA threats. The FIS had long given up their place as the bearers of hope. The party had to concede to this on 16 November. Their ambivalence with regard to the question of violence took away the trust of many of their former supporters. Liamine Zeroual, appointed by the military in 1994, was confirmed as head of government with 61,34 percent of the votes. ${ }^{66}$

On the one hand the voters had voted for the nationalistic Zeroual course, on the other hand, 25 percent, voted for a moderate Islam, for the Hamas. Algeria's future should not obey any extremism - neither that of a military dictatorship nor that of a Shari' $a$ state. The president had to understand his election as a demand to establish the promised antiterrorism and anti-corruption policy. Zeroual began his term of office with an offer of reconciliation to the armed Islamists. ${ }^{67}$

Algeria appeared to be actually treading the path away from the misery. At the beginning of Ramadan in 1996, the curfew imposed during the state of emergency was lifted, the country opened up to Western oil and gas investors, and France resumed the ferries between Marseilles and Algiers despite the continuing terror of the GIA. At the FLN party conference at the beginning of 1996, the anti-reform wing around general secretary Boualem Benhamouda gained the upper hand. The FLN concentrated

64

65

The offer to the negotiations was instigated by Madani and Belhadj who presented the proposal to the president in a letter.

This first positive step had a quick end because the government did not meet the order of demands of the two Islamists, who first of all demanded their release from detention and then cease-fire negotiations.

Schirmbeck, pp. $418-421$.

Zeroual called the armed fighters 'lost sons of the nation'. He offered them integration. 
themselves solely on the power which they had for 30 years. In February 1996 the state ordered a tightening of press censorship. Since then no pictures or reports about terrorist attacks have been allowed. Zeroual's promise to put an end to corruption followed the announcement that the meagre income of the workers and employees would be reduced in order to finance the outstanding wages of 200000 construction workers. The rage of those affected was great. A general strike paralysed the country for two days in February 1996. In this way the strikers wanted to force the state to take the missing public monies from the private accounts of corrupt civil servants.

The military and the old FLN cadre do not seem to want to understand the seriousness of the situation nor the wishes of the majority of the population, because with the continuation of the military policy, one wave of terrorism after another has rolled across the country. ${ }^{68}$ The Ramadan of 1997 was the last example of this which reawakened for a few weeks, the sensation-interest of Europe in Algeria.

\section{Concluding observations}

The problem with a country like Algeria is that democracy can only introduced in co-operation with Islam and not without it. That has got nothing to do with the FIS. This comes about because Islam defines politics in a different way. A world without God is unimaginable for the Algerians. The people want to keep their belief but they also want democracy. This is the problem. From this statement one can only conclude that Algeria must find its own way whereby citizens can live peacefully in an Islamic world. The west should reconsider its fear of Islam ${ }^{69}$ because differing religious parties also exist in Europe. Where Christian-Democratic or Christian-Socialist, they have even formed democratic governments. $^{70}$

In 1995 Algeria was offered a chance, because President Zeroual promised to create the basis for peace. This would have meant the release of Islamists in detention, most importantly Abassi Madani and Ali Belhadj, in order to enter into a dialogue with them. However nothing of the sort happened. It was as though the thread had been broken. Zeroual's political standstill cannot be clearly explained. Samuel Schirmbeck gives a possible motive as the murder of General Mohamed Boutighane, a friend of the president, a few hours after Zeroual's youth taking. Who were Boutighane's murderers? The Islamists, as was quickly conjectured, or the so-called eliminators in the army who wanted to predetermine the political route to be taken by the president? Or was Zeroual deceitful in the election campaign in order to stay in power? One thing is certain, the second democratic awakening in Algeria only lasted a short time, the people abandoned hope again. It is as though the sadness was floating through the streets of Algiers and settling

On 3 January 1995, a few weeks after Liamine Zeroual had been elected as president, the GIA published a communiqué in which they declared death to all Djazairistic heretics. The murders of civilians can be traced back to this declaration because, in 1995, many former FIS voters went to the elections, which also speaks for the final break with the Djazairistic FIS.

This fear is based on historical experience, as the Islamic fear of occidental modernism also has historical roots. The Europeans think of the second wave of the Muslim expansion which stretched from the Ottoman Empire to the gates of Vienna. However even the European feeling of superiority towards the Muslims is founded historically on the crusades and the victory of modernism in the form of colonialism.

It is obvious that the radicalism of a few Islamic parties and groups is damning the democratic policy - however there are not only these religious parties like the Algerian Hamas. On the whole these have caused the mistrust of the west towards all political religious groups in the Islamic world and obstructed the approach towards the opportunities out of the crisis and out of religious extremism. Europe must learn to co-operate with moderate Islamic parties. 
firmly on the facades and in the faces of the people. In November 1996 the Algerian prime minister Ahmed Ouyahia proudly announced to the international press that terrorism had been eliminated and Algeria was once more having a normal life. The selfconfidence of the new-old rulers increased with economic success. ${ }^{71}$

However, they were mistaken. Terrorism was reaching a climax, and the Ramadan of 1997 was to be a bloody 'orgy of hatred' where 400 people, mainly civilians, 'died. ${ }^{72}$ The Ramadan of 1998 was a bloody one as well. ${ }^{73}$

The government watched the drive of terrorism and waited until Zeroual declared in a 90 minute television speech on 24 January, that his dialogue-plan, which had been brought to life two years previously, would now end and total war on the Maquis was declared. The president did not speak about the suffering and misery of the people. Besides that terrorism, poverty and dissatisfaction increase daily because even basis foodstuffs have become almost beyond usual means due to escalating prices. Zeroual, the bringer of hope in 1995, had changed into a 'democratically' elected dictator.

This had been made clear at the end of the previous year by the referendum for the Constitution which he had changed ${ }^{74}$ in order to give the president far-reaching powers. The vote which followed on 28 November 1996 was manipulated, according to various eyewitnesses, because besides the democratic parties of the FFS and cheating at the elections. The accusation is that the actual election turnout as well as the approval of the constitution lay way below the figures presented by the government. ${ }^{75}$ The democratic opposition called for a boycott of the referendum because the new Constitution was after all serving to strengthen of the military dictatorship.

\section{European silence}

Europe left the hot and unpopular topic of Algeria to France, the former colonial master. France, the country of human rights, negotiated and supported only the 'government democrats' in Algiers, as prime minister Alain Juppe formulated it. The French government apparently does not ask about the question of the responsibility of the

The Algerian Minister of Energy is reckoning on an income of 600 million dollars per annum from oil and gas for the future. At the end of last year there was the largest joint venture between the Algerian government and British Petroleum. The IMF and the World Bank guaranteed high credit, and more is in view. The supposed oilfields in the region of In Salah justify the risk of international investment.

72 The most well known victim was the longstanding chairman of the former national trade union UGTA, Abdelkader Benhamouda, who was shot on 28 January. As with so many assassinations the intentions are not easily recognisable, although the state and French portrayal in the media accuses the GIA. Benhamouda was not only much appreciated overseas as a trade union leader, he was most of all an apparatchik who was co-responsible for the Algerian social misery. On the other hand he wanted to form a central party in 1997, in which sympathisers of the democratic and the religious sides should unite in a large opposition. The murderers could have come from the military who would have regarded such a party as an enemy. Cape Times, Cape Town, 22 December 1998.

74 According to this Constitution, in the future, besides the Parliament there will also be a 'Haute Chambre' (Senate), whose members will be personally named by the President which will enable him to use indirect influence on parliamentary decisions over and above the right of veto of the senate. Apart from this the new constitution states that Algeria is an Arabic Islamic country with Arabic as the official language and Islamic laws. With this, those in power in Algeria once more exclude the cultural and religious minorities of the country - this especially annoyed the FFS and RCD. This Constitution is lacking in democratic intention.

75 The election turnout would have been, according to this, 79,8 percent, and the yes votes would have been 85,8 percent. 
'democrats' for the misery, for the birth of the Islamists, for the flourishing of terrorism. ${ }^{76}$ Paris is still Algeria's most important foreign trading partner. They prefer to keep quiet about the abductions, torture and executions committed in the name of (military) democracy. If France keeps silent, so does Europe and the USA and the IMF/ World Bank, and all of them grant the regime in Algiers financial aid. The upholding of human rights is however not demanded. Why do the European intellectuals, the French scholars and artists keep silent, those who otherwise always raise their critical voices against injustice? The French philosopher Alain Finkelkraut ${ }^{77}$ speaks out for many. The problem is that one cannot see a solution. If one engages oneself it must be done in favour of one side. But in Algeria both sides (the military on the one side and the Islamic extremists on the other side) are unacceptable. The killing goes on. Europe is forced to be involved in the problem, because the orient and occident are not only geographically but also culturally-historically very close. Times of political and economic instability lead to migrations from the poor South to the wealthy North. Europe especially fears this sort of development. Already about ten million Muslims are living in Europe - one million Algerians in France alone. ${ }^{78}$ However, Europe showed little interest in the social integration of its non-European foreigners - the suburbs of French cities have developed into ghettos for Arabs and Africans. With the misery and boredom, high unemployment and crime that prevails in those areas, the Islamic teachings of the al-Nizam al-Islami appear as a message from a just world. The medieval cultural war could enter a new round, that of terrorism. ${ }^{79}$ The series of attacks in France was an initial warning - Europe must promote the social and political integration of its minorities as well as the cultural communication with them.

On the other hand the USA has fostered good contacts with the Islamic movements in Algeria for years because they believe that the Islamists will take over the political power. ${ }^{80}$ The question is only how - with a military victory, with a peaceful handing over of power in co-operation with and certainly under the control of the military, or with democratic elections? The Americans have learnt from the events in Teheran in 1979 and, contrary to the Europeans, they are pleading for political negotiations with the Islamists in order to motivate them to keep to the democratic rules of the game. ${ }^{81}$

76 On the other hand the chairman of the French socialists, Lionel Jospin, represents the opposite position, "Democracy, in the end, is the only road to peace." Lionel Jospin is quoted according to Roger Cohen, Rising Algeria Violence May Force West To Take Notice, in New YorkTimes of 3 February 1997.

77 Alain Finkelkraut, quoted according to Fredy Gsteiger.

78 The interesting topic of the European-Islamic relationship in Europe plays an important role in the Algerian problem in Le Monde, Paris, 7 October 1995.

Once more it must be mentioned that the west supported the Islamic querilla movement financially and logistically during the Cold War - in the end the west showed itself to be co-responsible for the origin of the double Islamic front - dissatisfied Muslims in Europe and the Maquis in the Islamic world.

80 The USA does not want to be once more confronted with circumstances like Iran - their strategy is that of dialogue, almost certainly with an eye on the supposed Algerian oil deposits. However this de-escalation policy was interrupted at the end of 1996 by the arrest of the FIS speaker Anwar Haddam who had been living in America exile for years.

81 The economic policy portrays the well-meant starting point for the gentle political pressure. On the other hand the well-known limits of the exertion of democratic influence lie in the economic policy, the oil interests. In any case the opposing dependencies appear to bring them closer together. 


\section{Is there a way out of the violence?}

The GIA is characterised by a high inner cohesion that makes them ultimately uncontrollable and hardly able to be manipulated from the outside. Young Algerians still go to the Maquis. The ruling clans are, as always, still not prepared to share their power and life of luxury with the population. "The powerful ones are ultimately only interested in staying in power." 82 The question is always being asked about the why of this dreadful excess of violence? As an answer Algerians point out the violent history of the eternal conquests and occupations of the country - last of all it was the violence of the French colonial power from which the Algerians freed themselves with a war that was carried out in a manner that was just as cruel. The present Jihad is directed against the corrupt cast of secular politicians, which is the principal cause of the economic and social misery of the majority of the people.

What role do the democrats play in this two-fronted war? Why do the Algerians apparently not trust them? The democrats, like thousands of other civilians, are the targets of attacks from both fronts and many have fled into exile. ${ }^{83}$ Others hide in their own country and others again do not allow themselves to be misled in their democratic engagement. But they have spread their own crisis, for they have handed over the field to the FIS. The democratic movement existed illegally and exclusively in intellectual francophone circles during the FLN rule. Their theoretically formulated criticism of society was directed at the state limitations on freedom - without becoming practical, and without recording the language and actual wishes of the citizens. Their biggest mistake was their absence from the social arena where the conflict was swelling and the Islamists were gathering their followers. As a result the democrats remained amongst themselves whereas the Islamists went out to the people. But even today, five years after the outbreak of the violent conflict, a few democrats still have little insight into why until now no united, strong opposition has been formed. Said Sadi, the party chairman of the RCD, rejects any form of dialogue with the Islamists, the murderers of the people. On the other hand, the RCD is working with the military government, for example they took part in the presidential elections in 1995. The party did not sign the 'Platform of Rome'. These democrats have to put up with the accusation that they are turning a blind eye to the cruel crimes committed by the military against the Islamists as well as against democrats and silent civilians. The question justifiably posed to them should be: are there no human rights for Islamists in the prisons and in police custody?

All participants in the conflict are demanding that the sources of evil should be named and that they should bear the political, economic and social consequences of their own actions. That does not mean that murder and terrorism should be understood or supported but the reasons that lead to murder and terrorism must be understood and analysed. This means also communicating with all the actors in the conflict by those who try to fund a peaceful solution. The 'Platform of Rome' declaration could be used as a basis for a peaceful solution in order to finally pull down the wall that has divided the country for years.

The conflict in Algeria is between the secular state power and the Islamist Maquis. Homogeneous groups form neither the state power nor the radical Islamists. There is

Khalida Messaoudi, the best known Algerian feminist in an interview with the Nouvel Observateur, Paris quote from die tageszeitung/ Berling of 16 February 1996, p. 12.

83

For example, Hocine Ait Ahmed, the chairman of the FFS, who returned to Algeria in 1990 after almost 30 years in exile and who left the country again at the beginning of the terrorism and now lives in Switzerland.
} 
rivalry between individual class within the Government, army and FLN apparatchiks. Only thus can the patches of 1965 and 1992 be explained. Furthermore, the radical Islamists are not homogeneous but they recruit from various groups who are also fighting amongst themselves e.g. FIS/ AIS versus GIA, which shows social and political differences. ${ }^{84}$

For the future of the country the following scenario is the most probable. Parliamentary fair and free elections would be planned for this year. These could lead to a victory for the moderate Islamic MSI Hamas, because the party of Sheikh Nahnah had already received 25 percent of the votes in 1995 (in the parliamentary elections of 1991 they could only get 5 percent). The MSI-Hamas support an Islamic society but reject the radical change. MSI-Hamas has satisfied its supporters with social and charitable work and made its mark on the side of the military government in the years after the breakingoff of the parliamentary elections in 1992. Today, because of its Islamic orientation, political experience (MSI-Hamas has taken part in the government since 1995), and its willingness to participate in dialogue, it could unite the former FIS-voters behind it and become the strongest party in parliament. The society model would be an Arab-Islamic national state, which would develop democratic procedures step by step and could become an example to its Maghreb neighbours. The social identification of the population, in all its cultural diversity, with the future state system is crucial for the societal integration of the Jihad fighters that would bring about the end of the violence.

As the leading personalities within the ANC established good relations during the liberation struggle with all the present actors in the Algerian conflict, they stand a good chance of playing a vital role as mediators. President Mandela enjoys the admiration and respect by all these actors in the Algerian conflict.

$\begin{array}{lll}\text { Abbreviations } & \\ \text { AIS } & - & \text { Armée Islamique du Salut / Islamic Salvation Army } \\ \text { ALN } & - & \text { Armée de Liberation Nationale / National Liberation Army } \\ \text { FFS } & - & \text { Front des Forces Socialistes / Front of Socialist Forces } \\ \text { FIS } & - & \text { Front Islamique du Salut / Islamic Salvation Front } \\ \text { FLN } & - & \text { Front de Libération Nationale / National Liberation Front } \\ \text { GIA } & - & \text { Groupe Islamique Armé / Armed Islamic Group } \\ \text { LADDH } & - & \text { Lique Algérienne des Droits de I'Homme / Algerian Human Rights League } \\ \text { MDA } & - & \text { Mouvement Democratique Algerienne / Algerian Movement for Democracy } \\ \text { MSI-Hamas } & - & \text { Mouvement pour une Société Islamique / Movement for an Islamic Society } \\ \text { PAGS } & - & \text { Parti de I'avantgarde Socialiste / Socialist Progress Party } \\ \text { PT } & - & \text { Parti des travailleurs / Worker's Party } \\ \text { RCD } & - & \text { Rassemblement pour la Culture et la Démocracie / Association for Culture and } \\ & & \text { Democracy } \\ \text { SIT } & - & \text { Syndicat Islamique due Salut / Islamic Salvation Union } \\ \text { UGTA } & - & \text { Union Nationale des Travailleurs Algériens / National Union of AlgerianWorkers }\end{array}$

84 Thus it was the Salafist wing of the FIS which announced in 1991 that, after an outright victory for the party in the elections, the 1989 Constitution would no longer be used and there would be an Islamic Republic, which shocked the democrats and the military and served to justify the military intervention in 1992. On the other hand, the moderate FIS wing and the MSI-Hamas are trying to link Islamic and democratic structures. 


\section{References}

Amnesty International: Jahresbericht 1996, Fischer, Frankfurt am main 1996, pp. $96-98$

Dan Diner, Weltordnung. Uber Geschichte und Wirkung von Recht und Macht, Fischer, Frankfurt am Main 1993, pp. 165-219.

Werner Herzog, Algerien Zwischen Demokratie und Gottesstaat, Beck, Munich 1995.

Amold Hottinger, Der Islamische Fundamentalismus, Wilhelm Fink Verlag, Munich 1993, pp. 158-170

Sabine Kebir, Algerien Zwischen Traum und Alptraum, Econ, Dusseldorf, Vienna, New York, Moscow 1995.

Gilles Kepel, Die Rache Gottes. Radikale Moslems, Christen und Juden auf dem Vormarsch. Piper, Munich 1991, pp. 32-75.

Andreas Meier, Der politische Auftrag des Islam. Programme und Kritik zwischen Fundamentalismus und Reformen aus der ilsamischen Welt., Peter Hammer Verlag, Wuppertal 1994.

Andreas Meier, Plitishce Stromungern in modernen Islam, Bundeszentrale fur politische Bildung, Bonn 1995.

Dieter Nohlen (ed.), Wörterbuch Staat und Politik, Bundeszentrale fur politische Bildung, Bonn 1996, pp. 178-181.

Samuel Schirmbeck, Hinder den Schleiern von Algiers, Hoffman und Campe, Hamburg 1996.

Bassam Tibi, Der religiöse Fundamentalismus im Ubergan zum 21. Jahrhundert, Bibliographisches Institut \& Brockhaus AG, Mannheid 1996.

Sigrid Faath, Die Rolle der politshen Parteien in den Magrebstaaten und die Aussichten der Demokratisieuring, in: KAS Auslands-Informationen, No. 6, 1996, pp. 31-40.

Michael Lemnertz, Der algerische Teufelskreis, in: Frankruter Allgemeine, 23 January 1997, pp. 1-2.

Moi, Khaled Kelkal, in: Le Monde, 7 October 1995, pp. 10-12.

Jean-Pierre Tuquoi, Les islamistes, du GLA ménacent d'intensifier la terreu en Algerie jusqu'à la fin du ramadan, in: Le Monde, 23 January 1997, pp. 1-2.

Jean-Pierre Tuquoi, Les pouvoir algerien est merme a tout dialogue et vent "exterminer" la guerilla islamiste and "Le pouvier table sur l'absorption progressive des islamistes politiques", in Le Monde, 26 and 27 January 1997, pp. 1-2.

Jean-Pierre Tuquoi, Le debat sur la crise algerienne est lance dans la classe politique francaise, in: Le Monde, 1 February 1997, p. 2.

Dominique Le Gulledoux, Nouvelles d'Algerie, in: Le Monde, 1 February 1997, p. 14.

Roger Cohen, Rising Algerian Violence May Force West to Take Notice, in: New York Times, 3 February 1997.

Tahar Ben Jelloun, Im Schatten der Vergangenheit, in: Die Zeit, 13 December 1996, p. 14.

Fredy Gsteiger, Lieber schiessen als reden, in: Die Zeit, 31 January 1997. P. 14.

Walter Wandler, Der Dialog in Algerien bleibt eingeschrankt, in: die Tageszeitung, 13 February 1997.

Walter Wandler, So, order so: Algerien wird islamaistisch, in: die Tageszeitung, 19 February 1997, p. 18.

Martin Barth, Iranische Verhaltnisse in Algerien, in: Der Tagesspiegel, 21 January 1997, p. 6.

The Algerian Slaughter, in: The Washington Post, 8 February 1997.

Sigrid Faath and Hanspeter Mattes, Die "Arabischen Afghanen" Faktor interner Konflikte in Nordafrika/Nahost und des internationalen Terrorismus, in Wuquf-Kurzanalysen, No 4, 20 August 1996. 